\title{
Rancang Bangun Sistem Informasi Manajemen Satu Atap (SIMTAP) Berbasis Web GIS (Geographic Information System)
}

\author{
Muhammad Idris ${ }^{1}$, Rudi Hariyanto ${ }^{2}$, Anang Aris Widodo ${ }^{3}$ \\ ${ }^{2}$ rudihariy4nto@gmail.com, ${ }^{3}$ anangariswidodo@gmail.com
}

Program Studi Teknik Informatika, Fakultas Teknologi Informasi, Universitas Merdeka Pasuruan

\begin{abstract}
The village head office is one of the government agencies that provides the data collection service of the population. The reality in Pohgading village still uses manual system in processing and data processing. Accurate, fast and accurate Population data is required. The main purpose of this research is the Population Data Collection System of Pohgading Village which is equipped with Web GIS (Geographic Information System). Methods taken by the author with observation, Interview, and Library Studies. The results of this study are expected to provide convenience in the data collection of the population. With the GIS Web system that displays the residential map of the population will be more leverage in the development of people and data collection will be easier.
\end{abstract}

Intisari- Kantor kepala desa merupakan salah satu instansi pemerintah yang memberikan pelayanan pendataan penduduk. Kenyataannya di desa Pohgading masih menggunakan sistem manual dalam pemrosesan dan pengolahan datanya. Pendataan Penduduk yang tepat, cepat dan akurat sangat di perlukan. Tujuan utama penelitian ini adalah merancang Sistem Pendataan Kependudukan Desa Pohgading yang di lengkapi dengan Web GIS (Geographic Information System). Metode yang diambil penulis yaitu dengan melaksanakan Observasi, Wawancara, dan Studi kepustakaan. Hasil dari penelitian ini diharapkan dapat memberikan kemudahan dalam pendataan penduduk. Dengan adanya sistem Web GIS yang menampilkan peta perumahan penduduk akan lebih maksimal dalam memantau perkembangan penduduk dan pendataannya akan lebih mudah.

Kata Kunci - Sistem Pendataan kependudukan, GIS (Geographic Information System), Web GIS

\section{PENDAHULUAN}

\section{A. Latar Belakang}

Kantor kepala desa merupakan salah satu instansi pemerintah yang memberikan pelayanan pendataan penduduk, terutama dalam proses pembuatan surat pengantar Kartu Tanda Penduduk (KTP), Kartu Keluarga (KK), Surat Kelahiran, Surat Kematian, Surat Keterangan Pindah dan lainlain. Juga memberikan informasi [5][6] masyarakat miskin dari setiap dusun di desa. Namun dalam kondisi riilnya masih menggunakan sistem [2][3] manual dalam pemrosesan dan pengolahan datanya [1].
Untuk dapat meningkatkan pendataan penduduk beserta laporan untuk pihak kecamatan, maka diperlukan langkahlangkah pengembangan sistem yang sudah berjalan.

Sistem pendataan penduduk ini [17] dirancang untuk membantu proses pendataan penduduk terutama dalam hal proses pendataan penduduk, kartu keluarga (KK), surat kelah iran, surat ke matian, dan surat keterangan pindah. Sistem ini juga dilengkapi dengan sistem GIS (Geographic Information System) sehingga letak geografis desa bisa dilihat langsung dengan satu sistem secara dinamis dan akurat dalam waktu yang singkat [16].

Manfaat sistem ini adalah untuk pembuatan laporan pendataan penduduk tersebut diatas dapat meminimalkan kesalahan dan keterlambatan pendataan penduduk yang seharusnya sudah masuk ke Kecamatan.

\section{KAJIAN PUSTAKA}

\section{A. Sistem Kependudukan}

Dewasa ini yang diartikan dengan sistem registrasi penduduk di Indonesia umu mnya yang menyangkut pelaporan dan pencatatan kelahiran, kematian, dan migrasi [11]. Peraturan Pemerintah Nomor 37 Tahun 2007 [9] menyatakan bahwa urusan adminitrasi kependudukan di kabupaten atau kota dilaksanakan oleh instansi pelaksana. Pelaksanaan pencatatan sipil yang meliputi peristiwa kelahiran, kematian, perkawinan, perceraian, pengakuan anak di kecamatan tertentu dilakukan oleh Unit Pelaksanaan Teknis Dinas (UPTD) instansi pelaksana. Dalam Peraturan Presiden Nomor 25 Tahun 2008 [10] menegaskan bahwa Petugas Registrasi adalah pegawai negeri sipil yang diberi tugas dan tanggung jawab memberikan pelayanan pelaporan penting serta pengolahan dan penyajian data kependudukan di desa atau kelurahan.

\section{B. PHP}

PHP atau Hypertext Preprocessor yang digunakan sebagai bahasa script server-side dalam pengembangan web yang disisipkan pada dokumen HTML [8]. Penggunaan PHP memungkinkan web [12][13] dapat dibuat dinamis sehingga maintenance situs web tersebut menjadi lebih mudah dan efisien [14][15][16].

\section{MYSQL}

MySQL sebenarnya merupakan turunan salah satu konsep utama dalam basis data yang telah ada sebelumnya; SQL (Structured Query Language). SQL adalah sebuah konsep pengopeasian basisdata, terutama untuk pe milihan atau seleksi 
dan pemasukan data yang memungkin kan pengoperasian data dikerjakan dengan mudah secara otomatis [4][7].

\section{GIS (Geographical Information System)}

GIS adalah alat bantu yang sangat esensial dalam menyimpan, memanipulasi, menganalisis dan menampilkan kembali kondisi-kondisi alam dengan bantuan data atribut dan data spasial yang dapat membantu dalam proses pengambilan keputusan [13]. GIS merupakan salah satu bentuk sistem informasi dengan penekanan pada informasi geografis yaitu mengenai tempat atau posisi suatu objek di permukaan bumi dan informasi mengenai keterangan atau atributnya.

\section{METO DE PENELITIAN}

Berdasarkan pengamatan yang dilakukan peneliti mengenai sistem informasi kependudukan di desa Pohgading penulis menemukan beberapa masalah antara lain :

1. Proses dan pencatatan data penduduk dan pembuatan laporan yang lamban.

2. Dalam hal komputerisasi di desa Pohgading hanya digunakan pengetikan surat-surat bersifat resmi, bukan digunakan untuk sistem pengolahan data penduduk.

3. Banyak data atau laporan yang tidak terarsip dengan baik.

Dari identifikasi permasalahan yang terjadi di desa Pohgading sistem informasi yang dibutuhkan oleh instansi desa Pohgading saat ini yaitu:

1. Informasi data penduduk yang akurat dan praktis dengan sistem yang terkomputerisasi.

2. Penyimpanan data yang fleksibel dan aman.

3. Kemudahan dalam pendataan, pencarian dan penyimpanan yang cepat dan akurat.

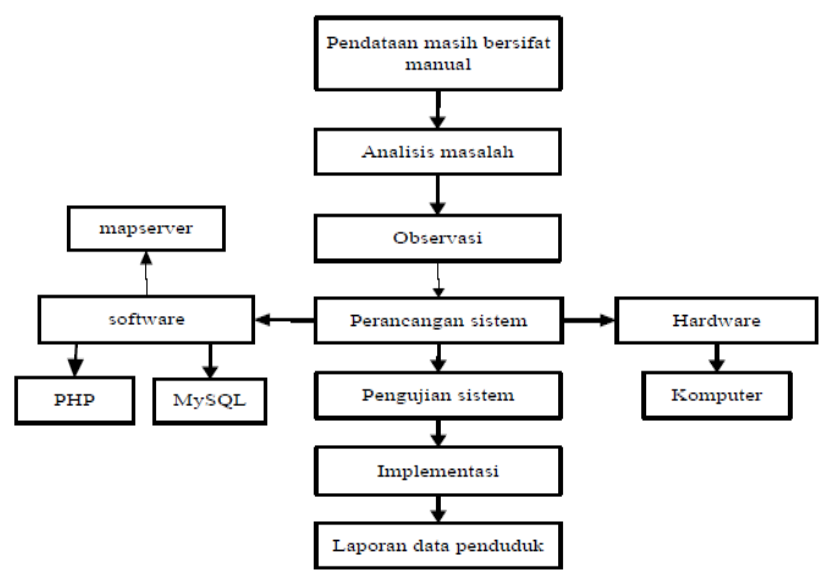

Gambar 1 Kerangka Pemikiran Sistem

Pada gambar 1 ditunjukkan Kerangka Pemikiran sebagai solusi masalah yang terjadi di desa Pohgading. Kerangka Pemikiran dikembangkan berdasarkan analisis kebutuhan dan informasi yang begitu banyak

1) Diagram Konteks

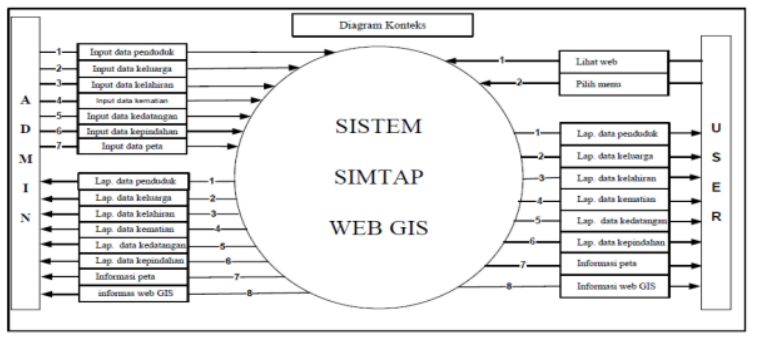

Gambar 2 Diagram Konteks/DFD 0 SIMTAP GIS

2) Flowchart Sistem

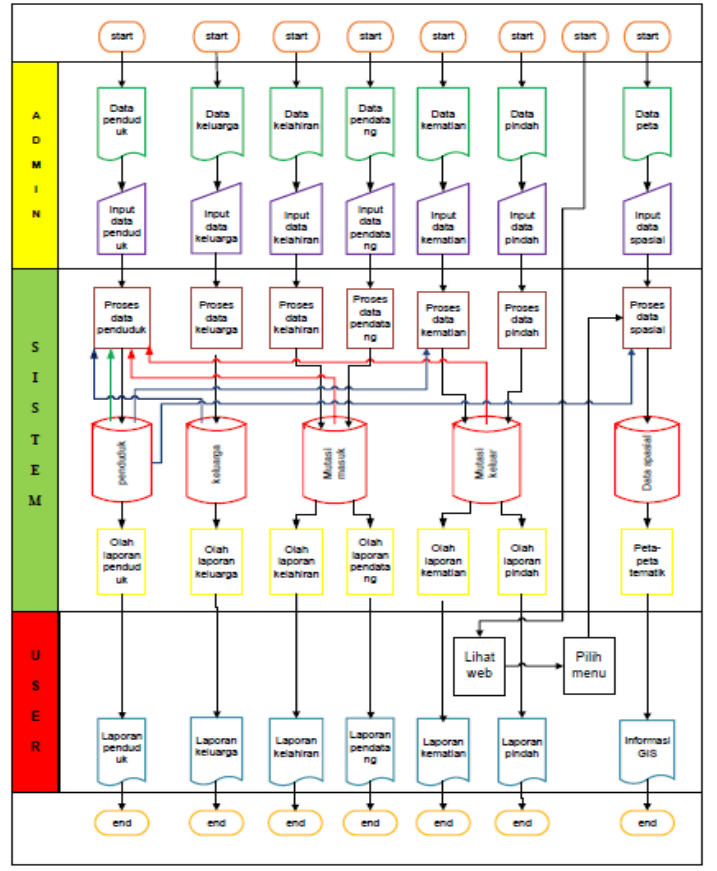

Gambar 3 Flowchart SIMTAP GIS

3) Entity Relationship Diagram

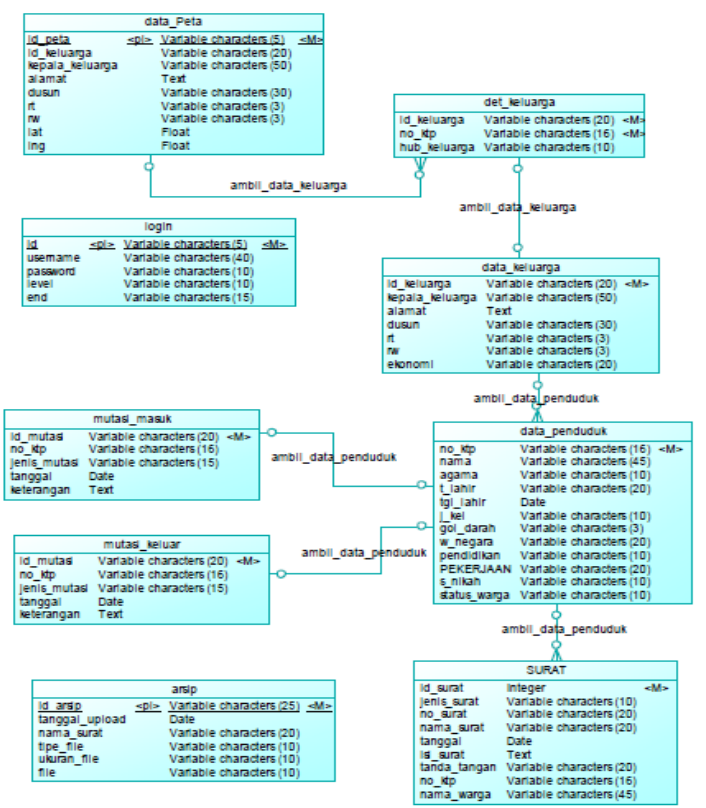

Gambar 5. ERD Pendataan Penduduk 


\section{HASIL DAN PEMBAHASAN}

\section{1) Halaman Utama}

Halaman utama website ini adalah untuk menampilkan menu informasi kepada masyarakat tentang laporan penduduk dan peta perumahan yang sudah terdata didesa Pohgading. Sehingga masyarakat bisa melihat letak rumah dan kepala keluarganya melalui sistem Rancang Bangun SIMTAP berbasis web GIS ini. Untuk masuk ke halaman utama ini tidak perlu login, sehingga semua masyarakat bisa melihat informasi tentang laporan penduduk dan melihat letak rumah penduduk desa Pohgading. Interface pada halaman utama seperti terlihat pada gambar di bawah ini.

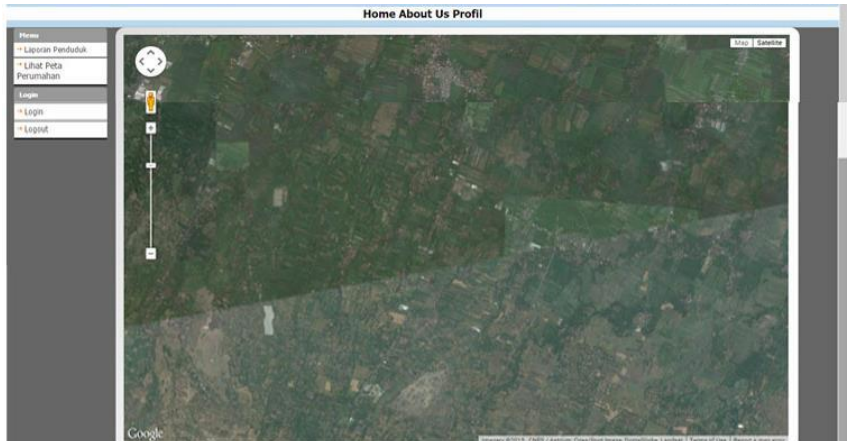

Gambar 6 Halaman Utama

Halaman website ini mempunyai beberapa menu yaitu laporan jumlah penduduk, penduduk lahir, penduduk wafat, penduduk pindah, penduduk datang dan lihat peta peru mahan. Halaman laporan penduduk memuat informasi tentang jumlah penduduk yang lahir, meninggal, datang dan pindah. Seperti pada gambar berikut.

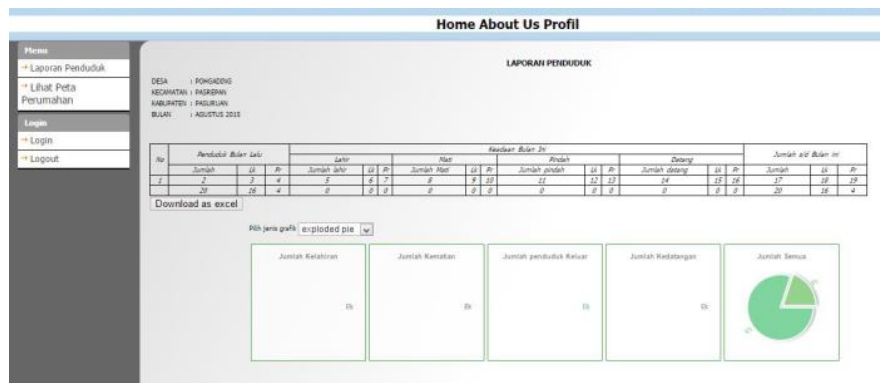

Gambar 7 Laporan Penduduk

Menu lihat peta perumahan menampilkan peta perumahan dan informasi kepala keluarganya dengan mengklik gambar rumah yang terdapat pada peta perumahan seperti pada gambar 8 berikut.

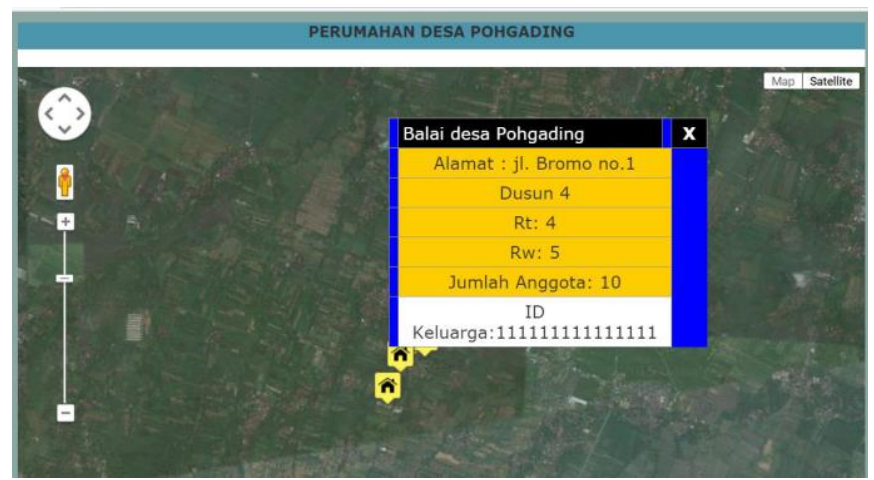

Gambar 8. Informasi Peta Perumahan Desa Pohgading
Pada menu Surat terdapat beberapa Sub menu, yaitu : surat kelahiran, surat kematian, surat keterangan pindah, surat keterangan adat istiadat, surat keterangan domisili, surat keterangan usaha,surat keterangan lainnya.

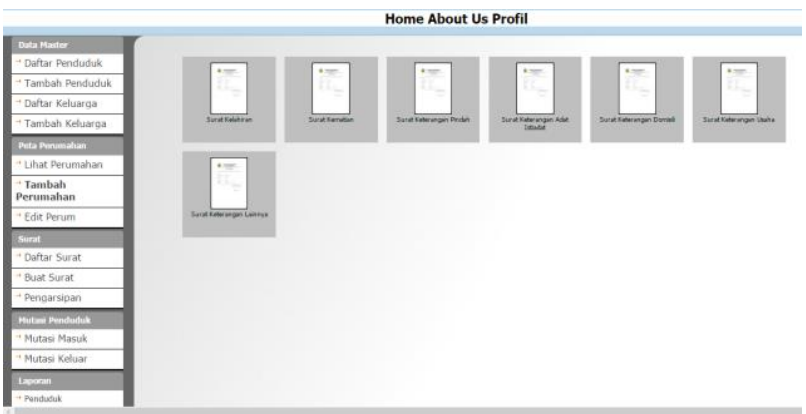

Gambar 10 Surat Pengantar

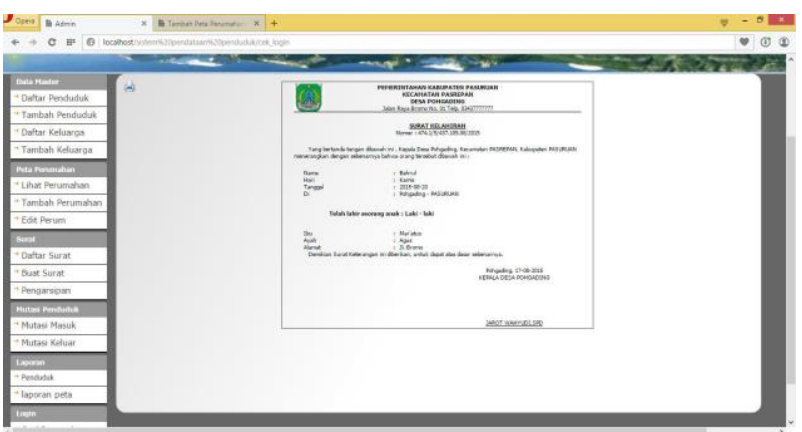

Gambar 11 Laporan Surat Kelahiran,

Kematian, Pindah, dan sebagainya

\section{KESIMPULAN DAN SARAN}

Penelitian yang dilakukan di Kantor kelurahan desa Pohgading dengan adanya aplikasi Rancang Bangun SIMTAP berbasis Web GIS ini, akan mempermudah, mempercepat, menciptakan efisiensi dan efektifitas kerja dalam mengatur Pendataan Penduduk. Selain itu juga untuk menginformasikan dan memonitoring semua daerah yang ada di desa Pohgading. Karena dengan tampilan peta perumahan dalam bentuk database akan lebih mudah diolah. Dari aplikasi ini nantinya dapat menampilkan peta perumahan penduduk sehingga lebih mudah melihat secara langsung persebaran dan perke mbangan pendudukdi desa Pohgading.

Penulis tahu dalam aplikasi Sistem Rancang Bangun SIMTAP berbasis Web GIS di desa Pohgading ini, masih banyak terdapat kelemahan dan kekurangan oleh sebab itu penulis menginginkan untuk penelitian selanjutnya. karena sistem web GIS ini dapat dikembangkan menjadi lebih bermanfaat dan lebih baik lagi.

\section{Ucapan Terima Kasih}

Penulis mengucapkan terima kasih kepada Bapak Rudi Hariyanto, S.Kom dan Bapak Anang Aris Widodo S.Kom yang telah membimbing untuk pembuatan jurnal ini. 


\section{DAFTAR PUSTAKA}

[1] Bunafit,N.( 2004). Database Relasional dengan MySql. Yogyakarta: Andi. Connolly.(2005). Database Sistem: A Practical Approach to Design, Implementation and Management. Addsion Wesley.

[2] Dwi,P.(2013).Sistem Informasi Data Penduduk Pada Desa Bogoharjo Kecamatan Ngadirojo Kabupaten Pacitan. IJNS - Indonesian Journal on Networking and Security,Vol 2 No.4 - Oktober 2013, ijns.org, ISSN:2302-5700.

[3] Rakhman,F.(2010).Sistem Informasi Geografis Sektor Pariwisata Kota Surabaya Berbasis Web. Skripsi. Surabaya: Teknik Informatika, Fakultas Teknologi Industri, Universitas Pembangunan Nasional "VETERAN".

[4] Aditya,A.N.(2011). Jago PHP \& MySQL. Bekasi: Dunia Komputer.

[5] Kadir,A.(2003). Pengenalan Sistem Informasi. Yogyakarta: Andi.

[6] Kristanto,A.(2004) . Perancangan Sistem Informasi dan Aplikasinya.

[7] Marlinda, L.(2004).Sistem Basis Data. Yogyakarta: Andi.

[8] Peranginangin.(2006). Aplikasi Dengan PHP dan MySQL. Yogyakarta: Andi.

[9] Peraturan Pemerintah Nomor 37 Tahun 2007 Tentang Administrasi Kependudukan.

[10] Peraturan Presiden Nomor 25 Tahun 2008 Tentang Persyaratan dan Tatacara Pendaftaran Penduduk dan Pencatatan Sipil.

[11] Prastyo,S.D.(2008).Sistem Informasi Pendataan Penduduk Pada Kantor Kepala Desa Ujungrusi Kabupaten Tegal. Media Elektrika, Vol.1, No. 2, 2008 : 20 - 30.

[12] Prihatna,H.(2005). Kiat Praktis Menjadi Web Master Profesional. Jakarta: Elex Media Komputindo.

[13] Ruslan,N(2005).Panduan MapServer. Bandung: Informatika.

[14] Sidik,B.(2001). Pemprograman Web Dengan PHP. Bandung:Informatika.

[15] Solichin,A.(2009).Pemrogaraman Web Dengan PHP Dan MYSQL. Jakarta: Universitas Budi Luhur.Prasetyo,D.(2004-2006).

[16] Pengembangan Sistem Informasi Geografis Tindak Kejahatan Multilevel berbasis Web. Jurusan Ilmu Komputer. IPB. Bogor.

[17] Pratama,S.Y.(2014).Perancangan Aplikasi Pendataan Kependudukan Desa Minomartani Sleman Yogyakarta. Naskah Publikasi. Yogyakarta : Sekolah Tinggi Manajemen Informatika Dan Komputer AMIKOM 